\title{
Two new species of the genera Pholcus and Spermophora (Araneae: Pholcidae) from the Nansei Islands, Japan
}

\author{
Teruo Irie
}

Ikeda 2-19-11, Kumamoto-shi, Kumamoto, 860-0082 Japan

\begin{abstract}
Two new species of the genera Pholcus and Spermophora belonging to the family Pholcidae are described from the Nansei Islands, Japan, under the names, Pholcus okinawaensis and Spermophora yanbaruensis
\end{abstract}

Key words - Pholcidae, Pholcus, Spermophora, new species, Kagoshima, Okinawa, Japan

Up to the present, in the genera Pholcus and Spermophora of the family Pholcidae, six and three species, respectively, have so far been recorded from Japan (Tanikawa 2000, 2001). Of these, four Pholcus and one Spermophora species have reported to occur in the Nansei Islands. They are Pholcus nagasakiensis Strand 1916, P. phalangioides (Fuessin 1775), P. yoshikurai Irie 1997 and P. zichyi Kulczński 1901, and Spermophora junkoae Irie 1997.

In this paper, I will add two species to the pholcid fauna of the islands by describing a new species of Pholcus from Yoron and Okinawa Islands, and a new species of Spermophora from Okinawa Island.

All the type specimens are deposited in the collection of the National Science Museum, Tokyo.

Abbreviations used are: ALE, anterior lateral eye; AME, anterior median eye; PLE, posterior lateral eye; PME, posterior median eye; $\mathrm{OA}$, ocular area; $\mathrm{Cp}$, length of clypeus.

I wish to express my sincere thanks to Dr. A. Tanikawa, Kanagawa and Mr. Takeshi Sasaki, Okinawa, for offering me invaluable specimens.

Pholcus okinawaensis n. sp.

[Japanese name: Okinawa-yûreigumo]

(Figs.1-7)

Diagnosis. This new species is similar to $P$. wuyiensis Zhu \& Gong 1991 known from China and $P$. yoshikurai Irie 1997 from Japan, in shape of the uncus of male palp, but is distinguished from them by having elevated ocular area of male (Fig. 2), male palpal trochanter basally with small prominences (Figs. 3-4) and a well-sclerotized genital plate of epigynum (Fig. 6). Unlike the former two species, this species is a house-dweller.

Male (holotype). Carapace pale brownish yellow, length nearly equal to width, with gray dorsal pattern. Eight eyes on a moderately elevated ocular area with pretty long hairs $(0.3-0.4 \mathrm{~mm})$, as shown in Figs. 1-2. Rows of anterior eyes procurved. Chelicera light brown, with a lamella and three short frontal apophyses, and with a sharp ridge on the lateral margin. Sternum light brown, slightly longer than width. Legs very long, yellowish brown; patellae, annulations in tips, bases of tibiae and metatasus brown. Leg formula 1, 2, 4,3 . Abdomen cylindrical, pale gray with dark gray markings.

Male palp: Uncus reddish dark brown; J-shaped, and frontally with minute prominences (Figs. 3-4). Procursus reddish brown.

Female (allotype): Body and legs slightly longer than those of male. Ocular area slightly lower than that of male without hairs. Epigynum (Figs. 6-7) glossy light brown. Other characters as in the male holotype.

Measurements of the holotype and allotype ( $\mathrm{s} / \mathrm{P}$; in $\mathrm{mm}$ ). Body length 4.33/4.46. Carapace length 1.33/1.33, width 1.33/1.46. Abdomen length 3.00/3.13, width 1.26/1.20.

Lengths of legs as shown in Table 1. Eye sizes: AME 0.07/0.07, ALE 0.16/0.18, PME 0.15/0.15, PLE 0.13/0.17. Distances between eyes; AME-AME 0.05/0.03, PME-PME $0.25 / 0.21$, ALE-ALE 0.27/0.27, PLE-PLE 0.47/0.42. OA length $0.27 / 0.31$, width $0.63 / 0.57$. Cp $0.33 / 0.20$.

Type series. Holotype đo (NSMT-Ar 5211), Tônanshokubutsu-rakuen, Okinawa-shi, Okinawa Prefecture, Japan, 24-VIII-2001. Allotype + (NSMT-Ar 5212), same locality, 7-VIII-2001. All the specimens collected by T. Irie.

Other specimens examined. 1우, Yoron Island, Kagoshima Pref., 19-V-1995, T. Irie leg. 1오 Sueyoshikoen, Naha-shi, Okinawa Pref., 4-IX-1997, T. Sasaki leg.

Distribution. Okinawa Island and Yoron Island, of the Nansei Islands, Japan.

Etymology. The specific name is derived from the native area. 

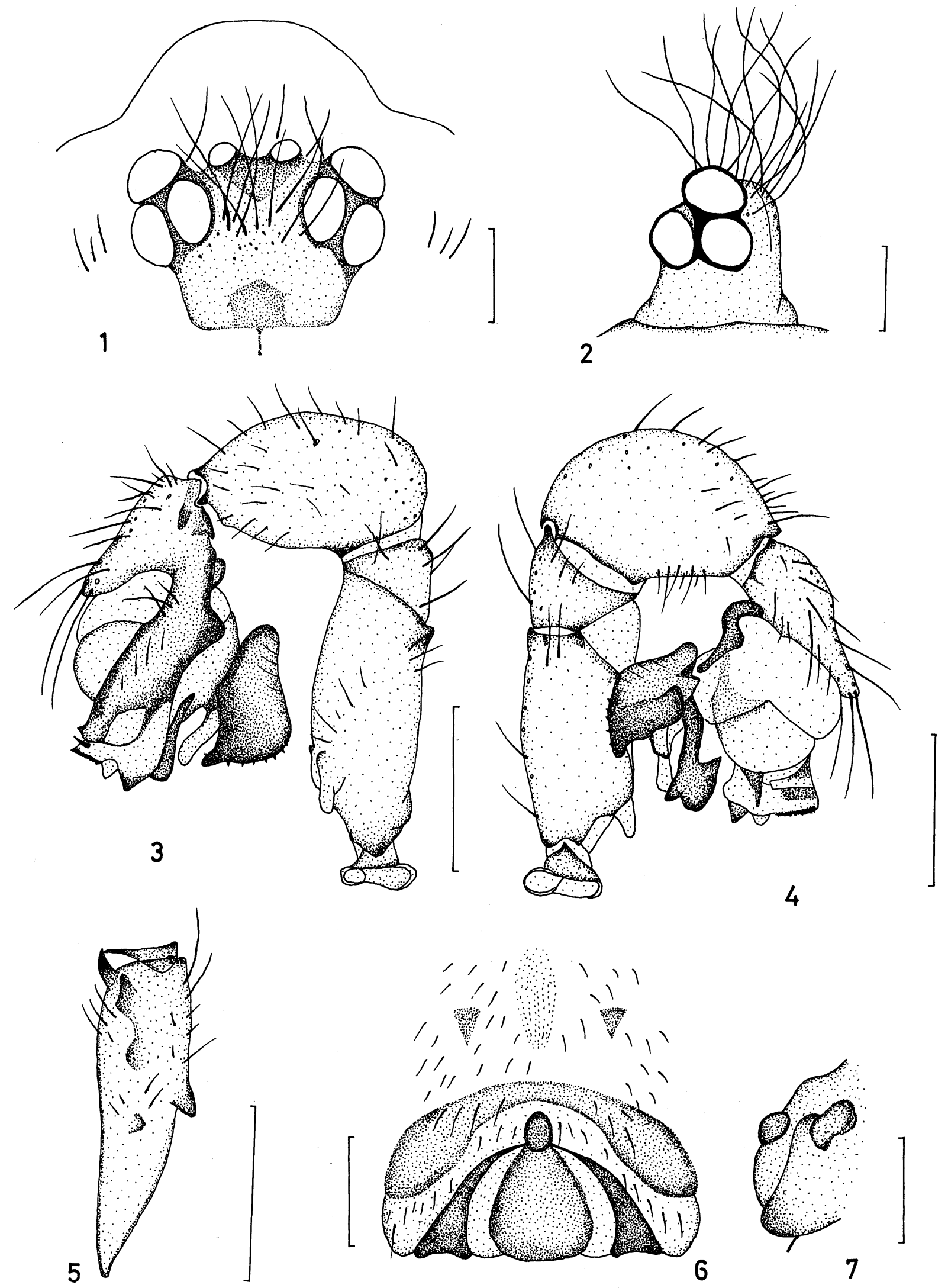

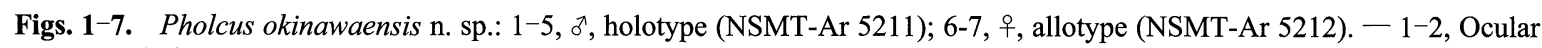
area, dorsal view (1); lateral view (2); 3-4, left palp, retrolateral view (3); prolateral view (4); 5, left chelicera, ventral view; 67, epigynum, ventral view (6); lateral view (7). (Scales: $1-2,6-7,0.2 \mathrm{~mm} ; 3-5,0.5 \mathrm{~mm}$ ) 
Table 1. Measurements of legs of Pholcus okinawaensis n. sp. ( $\sigma^{\top}$ holotype and 우 allotype italicized; in mm)

\begin{tabular}{cccccc}
\hline Leg & $\mathrm{Fe}$ & $\mathrm{Pa}+\mathrm{Ti}$ & $\mathrm{Mt}$ & $\mathrm{Ta}$ & Total \\
\hline I & 7.12 & 7.50 & 11.25 & 2.03 & 27.90 \\
& 7.25 & 7.87 & 11.62 & 1.93 & 28.67 \\
II & 5.37 & 5.25 & 6.25 & 1.26 & 18.67 \\
& 5.25 & 5.25 & 7.00 & 1.33 & 18.83 \\
III & 3.87 & 3.62 & 4.50 & 0.90 & 12.89 \\
& 3.87 & 3.62 & 4.75 & 0.90 & 13.14 \\
IV & 5.62 & 5.12 & 6.25 & 0.96 & 17.95 \\
& 5.62 & 5.37 & 6.75 & 0.56 & 18.30 \\
\hline
\end{tabular}

Spermophora yanbaruensis $\mathrm{n}$. $\mathrm{sp}$.

[Japanese name: Yanbaru-yûreigumo]

(Figs. 8-11)

Diagnosis. This new species is similar to Spermophora akebona Komatsu 1961 known from Honshu and Kyushu, in the shape of procursus of male palp (Fig. 9), but is easily distinguished from the species by having a dichotomized bulbal apophysis (Fig. 9) of palp in male and by having a central projection of epigynum (Fig. 11) in female. Unlike S. akebona which is usually found inside caves or under a cliffside rock, this new species is a leaf-dweller.

Male (holotype): Carapace pale brownish yellow, laterally with a pale gray belted spot, slightly longer than width. With six eyes, separated into two groups of triplet eyes. Chelicera pale yellow, with a long fang and lamella; a long brown prominence on the middle edge. Sternum pale yellow, slightly longer than width. Legs very long and slender, hairy, pale yellow in back ground with pale gray annulations in tip of the tibia and metatarsus. Abdomen pale brownish yellow with pale gray markings, oval, longer than width.

Male palp (Fig. 9): pale yellow, with a long spine on the procursus and a long bulbal apophysis.

Female (allotype): Body slightly longer than the male. Legs shorter than those of male. Epigynum (Fig. 11) pale brownish yellow. Other characters as same as in the male holotype.
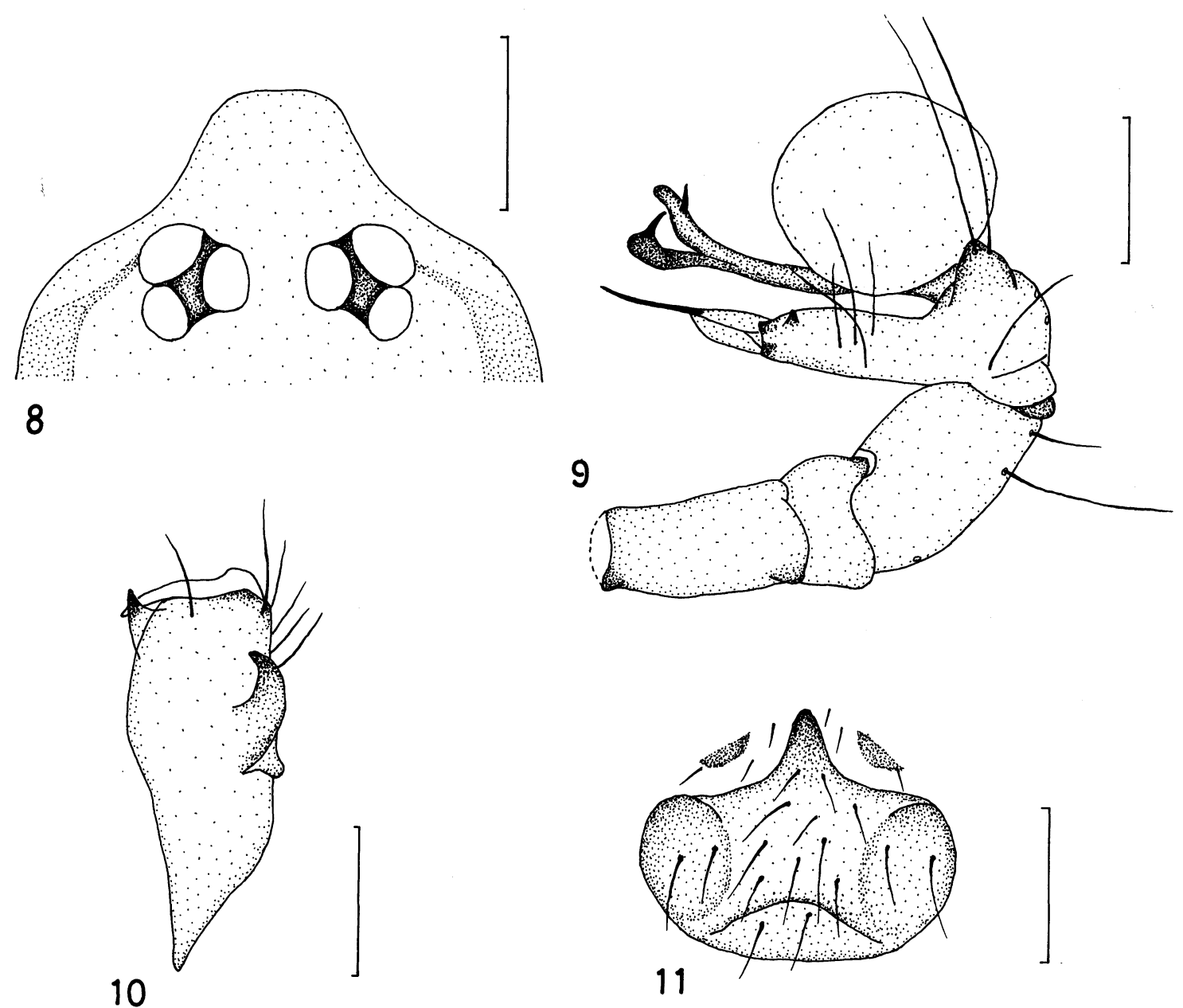

Figs. 8-11. Spermophora yanbaruensis n. sp.: 8-10, ð`, holotype(NSMT-Ar 5213); 11. ㅇ, allotype (NSMT-Ar 5214). - 8. Ocular area, dorsal view; 9, left palp, retrolateral view;10 left chelicera, ventral view; 11, epigynum, ventral view. (Scales: 0.2 $\mathrm{mm})$ 
Table 2. Measurements of legs of Spermophora yanbaruensis $\mathrm{n}$. sp. ( $\sigma^{\pi}$ holotype and + allotype italicized; in $\mathrm{mm}$ )

\begin{tabular}{cccccr}
\hline Leg & $\mathrm{Fe}$ & $\mathrm{Pa}+\mathrm{Ti}$ & $\mathrm{Mt}$ & $\mathrm{Ta}$ & Total \\
\hline I & 5.06 & 5.66 & 7.86 & 1.06 & 20.18 \\
& 3.36 & 3.80 & 5.00 & 1.36 & 13.52 \\
II & 3.83 & 3.90 & 5.16 & 0.90 & 13.79 \\
& 2.66 & 2.60 & 3.23 & 0.96 & 9.45 \\
III & 2.40 & 2.33 & 3.00 & 0.70 & 8.43 \\
& 1.80 & 1.66 & 2.03 & 0.56 & 6.05 \\
IV & 3.16 & 3.23 & 3.83 & 0.66 & 10.88 \\
& 2.46 & 2.46 & 3.03 & 0.63 & 8.58 \\
\hline
\end{tabular}

Measurements of the holotype and allotype ( $0 / 7$; in $\mathrm{mm}$ ). Body length 2.46/2.49. Carapace length 0.90/0.83, width 0.83/0.76. Abdomen length 1.56/1.66, width 0.96/1.13. Lengths of legs as shown in Table 2. Eye sizes; ALE 0.08/0.08, PME 0.10/0.09, PLE 0.08/0.08. Distances between eyes; ALE-ALE 0.30/0.25, PME-PME 0.12/0.12, PLE-PLE 0.30/0.29. OA length $0.17 / 0.16$, width $0.47 / 0.40$. Cp 0.21/0.15.

Variation (in mm). Body length: $\delta^{\top}, 2.10-2.50$; 우, 2.102.76 .

Type series. Male holotype (NSMT-Ar 5213) and female allotype (NSMT-Ar 5214), near the source of Zatsun River,
Kunigami-son, Kunigami-gun, Okinawa Pref., Japan, 1-IV1997, A. Tanikawa leg.

Other specimens examined. 1 우2 $0^{\lambda}$, near Benoki Dam, Kunigami-son, Kunigami-gun, Okinawa Pref., 30-III-1997; 4 우3 juv., same data as the holotype; 3우1 1 juv., Mt.Yonaha-dake, Kunigami-son, Kunigami-gun, Okinawa Pref. 2-IV-1997. All the specimens collected by A. Tanikawa.

Distribution. Okinawa Pref., Japan.

Etymology. The specific name is derived from the area name where the present new species was found.

\section{References}

Irie, T. 1997. Two new species of the genera Pholcus and Spermophora (Araneae: Pholcidae) from the Kyushu, Japan. Acta Arachnol., 46: 133-138.

Komatsu, T. 1961. Cave Spiders of Japan, Their Taxonomy, Chorology and Ecology. Arachnol. Soc. East Asia, Osaka, 91 pp.

Tanikawa, A. 2000. A check list of Japanese spiders (ver. 2000). Kishidaia, 78: 79-142. (In Japanese)

Tanikawa, A. 2001. Supplementary notes to a check list of Japanese spiders ver. 2000, 1. Kishidaia, 80: 151-155. (In Japanese)

Zhu, M. \& Gong, L. 1991. Four new species of the genus Pholcus from China (Araneae: Pholcidae). Acta Zool. Sinica, 16: 18-26.

Received May 10, 2002 / Accepted October 15, 2002 
従来ヒメアシダカグモに使用されていた Sinopoda stellata （Schenkel 1963）を日本のクモから削除した．同種は中国内陸 部に固有の種と考えられる。

スマトラ島のカブリダニ類（ダニ目：カブリダニ科）（pp. 125133

江原昭三（勇680-0001 鳥取市浜坂 2丁目 15-7）（pp. 125-133）

高藤晃雄氏（京都大学）が 1981 年 12 月にインドネシアのス マトラ島で種々の植物から採集した標本が，この研究に用いら れた. 12 種のカブリダニが同定され，この中の 1 種は新種で, Amblyseius (A.) sumatrensis として記載された。他の 11 種はす べてスマトラからの新記録種である。これらのうち, 従来あま りょく知られていない Amblyseius (Neoseiulus) circellatus Wu \& Li 1983, および Paraphytoseius seychellensis Schicha \& CorpuzRaros 1985 については, 再記載が与えられた。前者の雄はこの たび初めて記載された，残りの種の大部分については，主要な 識別形質が記述された.

中国地方産のモリヒメグモ属（クモ目：ヒメグモ科）の 3 種 (pp. 135-137)

吉田 哉 (下990-2484 山形市篭田 2丁目 7 番 16 号)

中国地方からモリヒメグモ属 Robertus の 3 種を記録した。 そのうちの 1 種, ノジマモリヒメグモ（新称） R. nojimai, を 新種として記載した。その他の 2 種, キタモリヒメグモ $R$. sibiricus Eskov 1987 抢よびサイトウモリヒメグモ R. saitoi Yoshida 1995，を岡山県および鳥取県から初めて記録した。 キ タモリヒメグモは本州新記録となる。
長野県産のタカユヒメグモ属（クモ目：ヒメグモ科）の 1 新種 (pp. 139-140)

吉田 哉（广990-2484 山形市篭田 2丁目 7 番 16 号）

長野県産のヒメグモ科タカユヒメグモ属 Takayus の 1 新種を フジサワヒメグモ（新称）T. fujisawai の名前で記載した. 高 山村山田牧場の上部標高 $1,750 \mathrm{~m}$ ほどの尾根部分で, ウラジロ モミ（ダケモミ）Abies homolepis Sieb. \& Zucc.に網を張ってい るところを採集された。

南西諸島産のユウレイグモ属およびシモングモ属（クモ目，ユ ウレイグモ科) の 2 新種 (pp. 141-144)

入江照雄（下860-0082 熊本市池田 2 丁目 19-11）

南西諸島産のユウレイグモ科の 2 新種, Pholcus okinawaensis オキナワユウレイグモ(新称, 沖縄島産, 与論島産)打よび Spermophora yanbaruensis ヤンバルユウレイグモ（新称, 沖縄 島産）を記載した。

日本初記録のソルホイオニダニ（ササラダニ亜目 : オニダニ科） (pp. 145-147)

島野智之 ${ }^{1}$, 坂田知世 ${ }^{2}$, Roy A. Norton ${ }^{2}$ ('T960-2156 福島市荒 井字原宿南 50 東北農業研究センター烟地利用部 畑土壌管 理研究室; ${ }^{2}$ College of Environmental Science and Forestry, State University of New York, USA)

Camisia solhoeyi Colloff（ソルホイオニダニ, 新称）を初めて 日本から記録した，本種は，胴背毛 $\mathrm{h} 1$ が他の胴背毛よりあ短 いという特徴によって日本に生息する他の近縁な種と区別でき る. よく知られている C. lapponica (Trägårdh) は, 本種と非常 によく似て抢り, 以前の C. lapponica の日本での記録は, 再調 查される必要があるかも知れない. 